\title{
CALIBRATION OF RADIOCARBON DATES FOR THE LATE PLEISTOCENE USING U/Th DATES ON STALAGMITES
}

\author{
JOHN C. VOGEL
}

Council for Scientific and Industrial Research, Box 395, Pretoria, South Africa 0001

and

JOEL KRONFELD

Department of Geophysics, University of Tel Aviv, Ramat Aviv, Israel

\begin{abstract}
Twenty paired ${ }^{14} \mathrm{C}$ and U/Th dates covering most of the past $50,000 \mathrm{yr}$ have been obtained on a stalagmite from the Cango Caves in South Africa as well as some additional age-pairs on two stalagmites from Tasmania that partially fill a gap between $7 \mathrm{ka}$ and $17 \mathrm{ka}$ ago. After allowance is made for the initial apparent ${ }^{14} \mathrm{C}$ ages, the age-pairs between $7 \mathrm{ka}$ and 20 ka show satisfactory agreement with the coral data of Bard et al. $(1990,1993)$. The results for the Cango stalagmite between $25 \mathrm{ka}$ and $50 \mathrm{ka}$ show the ${ }^{14} \mathrm{C}$ dates to be substantially younger than the U/Th dates except at $49 \mathrm{ka}$ and $29 \mathrm{ka}$, where near correspondence occurs. The discrepancies may be explained by variations in ${ }^{14} \mathrm{C}$ production caused by changes in the magnetic dipole field of the Earth. A tentative calibration curve for this period is offered.
\end{abstract}

\section{INTRODUCTION}

At the International Radiocarbon Conference in Bern in 1978, it was pointed out that certain ${ }^{14} \mathrm{C}$ dates for the Late Pleistocene appear to be several thousand years too young when compared with corresponding uranium series dates (Vogel 1980; Barbetti 1980). This prompted us to undertake a more detailed comparison of the two dating techniques using a slender $2.8 \mathrm{~m}$ stalagmite from the Cango Caves in the Cape Province of South Africa. This specimen, which stood at the far end of Cave II, was sawed into sections and removed during several visits over a period of four years. It proved to be ideal for the purpose since it had a coarse crystalline nonporous structure that ensured closed-system conditions. Its base turned out to date back nearly 50,000 yr; water was dripping onto the tip so that it was still growing at the time of removal. Preliminary results for the comparison were reported at the next Radiocarbon Conference in Seattle in 1982 (Vogel 1983).

Unfortunately there is a gap in the sequence, because the stalagmite's growth halted between $c a$. 17,000 and $7000 \mathrm{yr}$ ago. This gap could partially be filled by samples of two similarly crystalline stalagmites from Lynd's Cave in Tasmania (Vogel 1987; Goede and Vogel 1991).

\section{METHOD}

We cut samples along the growth axis of the three stalagmites and performed the ${ }^{14} \mathrm{C}$ and $\mathrm{U} / \mathrm{Th}$ analyses using the same pieces in each case. Carbon dioxide for measurement of the ${ }^{14} \mathrm{C}$ in a $\mathrm{CO}_{2}$ proportional counter was generated by adding acid, and the remaining solution was processed for the $\mathrm{U} /$ Th isotope analysis, using standard $\alpha$-counting techniques.

\section{RESULTS}

The results for the Cango stalagmite are given in Table 1, and those for Lynd's Cave are listed in Table 2. Two adjustments need to be made to the dates.

1. The ${ }^{14} \mathrm{C}$ ages must be corrected for the apparent initial age of the calcite when it is precipitated from the dripping groundwater. 
As previously shown (Vogel 1983), the first six ${ }^{14} \mathrm{C}$ dates for the upper $95 \mathrm{~cm}$ of the Cango stalagmite show complete concordance with the $\mathrm{U} / \mathrm{Th}$ dates if $1450 \mathrm{yr}$ are subtracted from the initial age and the results are calibrated with the tree-ring calibration curve (e.g., Stuiver and Pearson 1993). This correction of $1450 \mathrm{yr}$ is thus adapted for the older sections, too. It is, of course, possible that the apparent initial age varied with differing climatic conditions, but the shift would not have been more than a few hundred years, since this figure has been found to apply to groundwater in limestone areas worldwide. The adjustment for the Lynd's Cave stalagmites is less certain. $1500 \mathrm{yr}$ are subtracted from these ${ }^{14} \mathrm{C}$ dates, but an error of \pm 500 should be assumed. When these results were first presented (Vogel 1987) $2160 \mathrm{yr}$ was subtracted, based on a comparison with parallel electron spin resonance (ESR) dates, but subsequent tree-ring calibration data for the early Holocene (Kromer and Becker 1993) have shown this correction to be too large.

2. The U/Th ages need to be corrected for any initial ${ }^{230} \mathrm{Th}$ that may have been incorporated into the stalagmite during formation.

Most of the samples had very small amounts of ${ }^{232} \mathrm{Th}$. For those that did show measurable amounts of the isotope, the adjustment was $<230 \mathrm{yr}$, assuming an initial ${ }^{230} \mathrm{Th} /{ }^{232} \mathrm{Th}$ activity ratio of $1 \pm 0.5$. An exception was the Lynd's Cave stalagmite $L 1$, which had a very low uranium content ( $c a .0 .02 \mathrm{ppm}$ ) and consequently required a correction of $620 \mathrm{yr}$ in one case. The $\mathrm{U} / \mathrm{Th}$ results from this specimen are therefore less precise than the rest.

TABLE $1 .{ }^{14} \mathrm{C}$ and U/Th data for Cango stalagmite V3. Column 2 gives the distance of the sample from the tip of the stalagmite; column 4 the apparent ${ }^{14} \mathrm{C}$ age adjusted for isotope fractionation using the ${ }^{13} \mathrm{C} /{ }^{12} \mathrm{C}$ ratio. Columns 7,8 and 9 list the activity ratios of the $U$ and Th isotopes and column 10 the $U$-series ages adjusted for initial Th.

\begin{tabular}{|c|c|c|c|c|c|c|c|c|c|}
\hline Sample & $\begin{array}{c}\text { Distance } \\
(\mathrm{mm})\end{array}$ & $\begin{array}{c}\text { Lab code } \\
\text { (Pta-) }\end{array}$ & $\begin{array}{c}\text { Apparent }{ }^{14} \mathrm{C} \\
\text { age (yr BP) }\end{array}$ & $\begin{array}{c}\text { Anal. } \\
\text { no. }\end{array}$ & $\begin{array}{l}\text { U cons } \\
\text { (ppm) }\end{array}$ & $\frac{{ }^{234} \mathrm{U}}{{ }^{238} \mathrm{U}}$ & $\frac{{ }^{230} \mathrm{Th}}{{ }^{232} \mathrm{Th}}$ & $\frac{{ }^{230} \mathrm{Th}}{{ }^{234} \mathrm{U}}$ & $\begin{array}{c}\mathrm{U} / \mathrm{Th} \\
\text { age (yr BP) }\end{array}$ \\
\hline V3/1a & 5 & 2256 & $1530 \pm 50$ & U-003 & 0.068 & 3.70 & -- & -- & recent \\
\hline $\mathrm{V} 3 / 1 \mathrm{~b}$ & 14 & & & -- & -- & -- & & & \\
\hline $\mathrm{V} 3 / 1 \mathrm{c}$ & 314 & 2579 & $3270 \pm 45$ & U-107 & 0.062 & 3.43 & 10 & 0.019 & $1870 \pm 220$ \\
\hline $\mathrm{V} 3 / 1 \mathrm{~d}$ & 492 & 2289 & $4660 \pm 60$ & & & & & & \\
\hline$V 3 / 2 a$ & 7 & 30 & 5730 & U-108 & 0.098 & 3.61 & 28 & 0.044 & $4710 \pm 350$ \\
\hline$V 3 / 2 b$ & 8 & 2581 & 6380 & U-109 & 0.109 & 3.59 & 101 & 0.057 & $6240 \pm 400$ \\
\hline$V 3 / 2 c$ & 974 & 2 & 40 & U-112 & 0.091 & 3.14 & 217 & 0.152 & 17,400 \\
\hline /6a & & 1 & 1 & U-263 & 0.109 & 3.15 & $\gg$ & 0.166 & $19,300 \pm 800$ \\
\hline $6 \mathrm{~b}$ & 11 & 7 & 1 & & & & & & \\
\hline $\mathrm{V} 3 / 6 \mathrm{c}$ & 1304 & & 2 & U-242 & 0.140 & 2.65 & $>>$ & 0.227 & 00 \\
\hline $\mathrm{V} 3 / 3 \mathrm{~m}$ & 151 & 3 & 10 & U-265 & 0.078 & 3.18 & 103 & 0.227 & 27,2 \\
\hline $\mathrm{V} 3 / 3 \mathrm{~b}$ & 1 & & & U-282 & 0.101 & 3.10 & 256 & 0.264 & $32,100=$ \\
\hline $\mathrm{V} 3 / 4 \mathrm{a}$ & 1679 & 2657 & \pm 610 & U-118 & 6 & 3.02 & $\gg$ & 0.242 & $29,200=$ \\
\hline $\mathrm{V} 3 / 4 \mathrm{c}$ & 1759 & 3078 & +180 & U-264 & 0.083 & 3.22 & $\gg$ & 0.243 & \pm 3000 \\
\hline $\mathrm{V} 3 / 4 \mathrm{~d}$ & 1842 & 7 & \pm 180 & U-266 & 0.073 & 2.99 & 153 & 0.282 & 2200 \\
\hline$V 3 / 4 b$ & 2030 & 2658 & 30,1 & U-119 & 0.083 & 3.18 & 173 & 0.287 & $35,200 \pm 1000$ \\
\hline $\mathrm{V} 3 / 5 \mathrm{a}$ & & & 32,6 & U-269 & 0.077 & 3.03 & $\gg$ & 0.294 & $0 \pm 1800$ \\
\hline $\mathrm{V} 3 / 5 \mathrm{c}$ & 2181 & 3893 & $33,870 \pm 330$ & U-325 & 0.087 & 3.05 & 155 & 0.305 & \pm 1200 \\
\hline $\mathrm{V} 3 / 5 \mathrm{~b}$ & 2288 & 2689 & $35,900 \pm 280$ & U-136 & 0.058 & 3.11 & 255 & 0.311 & $0 \pm 900$ \\
\hline $\mathrm{V} 3 / 7 \mathrm{a}$ & 2409 & 3278 & \pm 300 & U-270 & 0.109 & 2.84 & 254 & 0.329 & $0 \pm 1200$ \\
\hline $\mathrm{V} 3 / 7 \mathrm{~d}$ & 2491 & 3887 & $37,580 \pm 490$ & U-324 & 0.117 & 2.85 & 200 & 0.348 & $0 \pm 1400$ \\
\hline $\mathrm{V} 3 / 7 \mathrm{c}$ & 2589 & 3884 & & U-323 & 0.107 & 2.90 & 200 & 0.352 & $44,700 \pm 1400$ \\
\hline $\mathrm{V} 3 / 7 \mathrm{~b}$ & 2698 & 3280 & $47,660 \pm 1120$ & U-283 & 0.119 & 2.73 & 420 & 0.381 & $49,200 \pm 1300$ \\
\hline
\end{tabular}


TABLE $2 .{ }^{14} \mathrm{C}$ and $\mathrm{U} / \mathrm{Th}$ data for the Tasmanian stalagmites. (See Table 1 for explanation.)

\begin{tabular}{|c|c|c|c|c|c|c|c|c|c|}
\hline Sample & $\begin{array}{l}\text { Distance } \\
(\mathrm{mm})\end{array}$ & $\begin{array}{c}\text { Lab code } \\
\text { (Pta-) }\end{array}$ & $\begin{array}{c}\text { Apparent }{ }^{14} \mathrm{C} \\
\text { age (yr BP) }\end{array}$ & $\begin{array}{c}\text { Anal. } \\
\text { no. }\end{array}$ & $\begin{array}{l}\text { U cons } \\
\text { (ppm) }\end{array}$ & $\frac{{ }^{234} U}{238 U}$ & $\frac{{ }^{230} \mathrm{Th}}{{ }^{232} \mathrm{Th}}$ & $\frac{{ }^{230} \mathrm{Th}}{{ }^{234} \mathrm{U}}$ & $\begin{array}{c}\mathrm{U} / \mathrm{Th} \\
\text { age (yr BP) }\end{array}$ \\
\hline \multicolumn{10}{|c|}{ Lynd's Cave stalagmite L2 } \\
\hline $\mathrm{L} 2 / 1$ & 717 & 3792 & $10,980 \pm 110$ & U-305 & 0.307 & 3.12 & 171 & 0.104 & $11,740 \pm 500$ \\
\hline $\mathrm{L} 2 / 2$ & 515 & 3791 & $11,800 \pm 100$ & & & & & & \\
\hline $\mathrm{L} 2 / 4$ & 334 & 3707 & $12,770 \pm 100$ & U-293 & 0.262 & 2.97 & 236 & 0.117 & $13,300 \pm 360$ \\
\hline $\mathrm{L} 2 / 3$ & 120 & 3708 & $13,450 \pm 130$ & U-294 & 0.305 & 2.85 & 442 & 0.128 & $14,570 \pm 420$ \\
\hline \multicolumn{10}{|c|}{ Lynd's Cave stalagmite L1 } \\
\hline $\mathrm{L} 1 / 3$ & 1380 & 3762 & $8320 \pm 90$ & U-301 & 0.019 & 2.32 & 12 & 0.069 & $7070 \pm 570$ \\
\hline L1/6 & 980 & 3731 & $10,970 \pm 100$ & U-299 & 0.016 & 2.69 & 64 & 0.099 & $11,080 \pm 800$ \\
\hline $\mathrm{L} 1 / 7$ & 614 & 3797 & $12,400 \pm 110$ & & & & & & \\
\hline L1/9 & 79 & 3713 & $14,170 \pm 60$ & U-295 & 0.024 & 2.80 & 44 & 0.114 & $12,840 \pm 750$ \\
\hline
\end{tabular}

\section{Discussion}

With these two adjustments to the ages, the results for the Cango stalagmite are plotted (Fig. 1.) against the distance from the tip. A few of the U/Th analyses had relatively large margins of error, but on the whole they show a nearly linear growth of the stalagmite between $44 \mathrm{ka}$ and $18 \mathrm{ka}$ ago, with a somewhat slower growth rate between $49 \mathrm{ka}$ and $44 \mathrm{ka}$. The ${ }^{14} \mathrm{C}$ ages, on the other hand, show major deviations from this linear growth curve, especially for the period beyond $30,000 \mathrm{yr} \mathrm{BP}$, where they are consistently several thousand years younger than the uranium series dates.

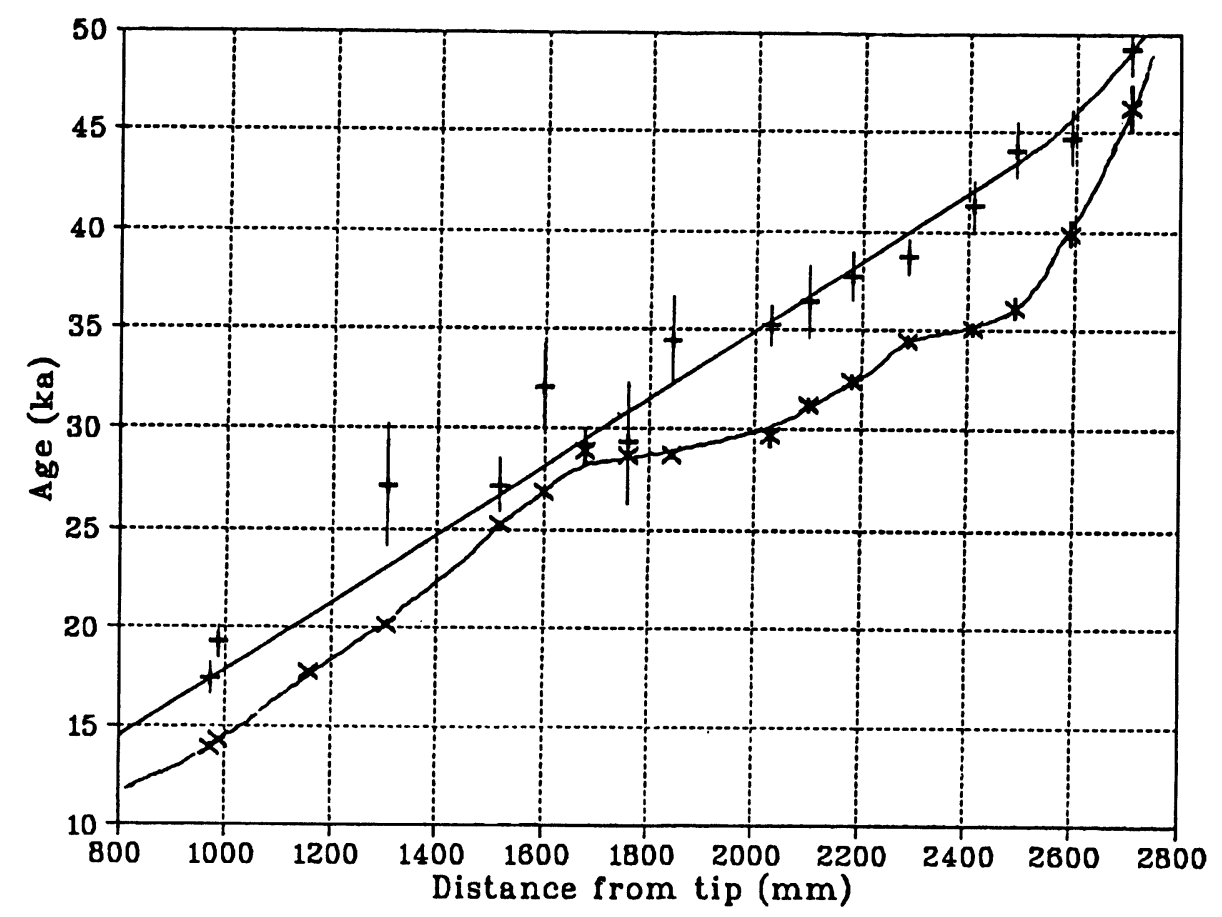

Fig. $1 .{ }^{14} \mathrm{C}$ dates $(メ)$ adjusted for initial age of $1450 \mathrm{yr}$ and parallel $\mathrm{U}$-series dates $(+)$ for the Cango stalagmite showing the large discrepancy between age-pairs between $30 \mathrm{ka}$ and $45 \mathrm{ka}$ 
Now, it is well known that samples older than $30,000 \mathrm{yr}$ are prone to produce ${ }^{14} \mathrm{C}$ ages that are too young due to contamination by small amounts of more recent carbon. The fact that the ${ }^{14} \mathrm{C}$ date for the bottommost sample agrees with the U/Th age to within $1 \sigma$ if the correct ${ }^{14} \mathrm{C}$ half-life $(5730 \mathrm{yr})$ is used $\left(49,200 \pm 1300(\mathrm{U} / \mathrm{Th})-47,550 \pm 1120\left({ }^{14} \mathrm{C}\right)=1650 \pm 1720\right)$, indicates, however, that contamination cannot in this case explain the discrepancies between the two methods. Of special significance is near identity between the ${ }^{14} \mathrm{C}$ and $\mathrm{U} / \mathrm{Th}$ ages $c a .29,000 \mathrm{yr}$ ago. This will be discussed briefly below.

For the period between 10 and 20 ka we need to consider the age-pairs derived from the two Lynd's Cave stalagmites (Table 2). As previously noted (Vogel 1987), these data also show considerable discrepancies between the ${ }^{14} \mathrm{C}$ ages and the $\mathrm{U} / \mathrm{Th}$ ages.

More recently, a comprehensive set of age comparisons has been published using coral from Barbados (Bard et al. 1990, 1993), which confirm that ${ }^{14} \mathrm{C}$ dates between $12 \mathrm{ka}$ and $22 \mathrm{ka}$ are several thousand years too young. The $\mathrm{U} / \mathrm{Th}$ dates were produced by thermal ionization mass spectrometry (TIMS), which gives greater precision than the conventional $\alpha$-counting technique. In Figure 2 these results are presented together with our measurements in this time range; two pairs from Cango (V3) are also included to extend the age range. All except two of our data points correspond to the TIMS results to within one sigma, thus confirming that the ${ }^{14} \mathrm{C}$ age discrepancy is a worldwide phenomenon and that the stalagmite data do represent the actual situation.

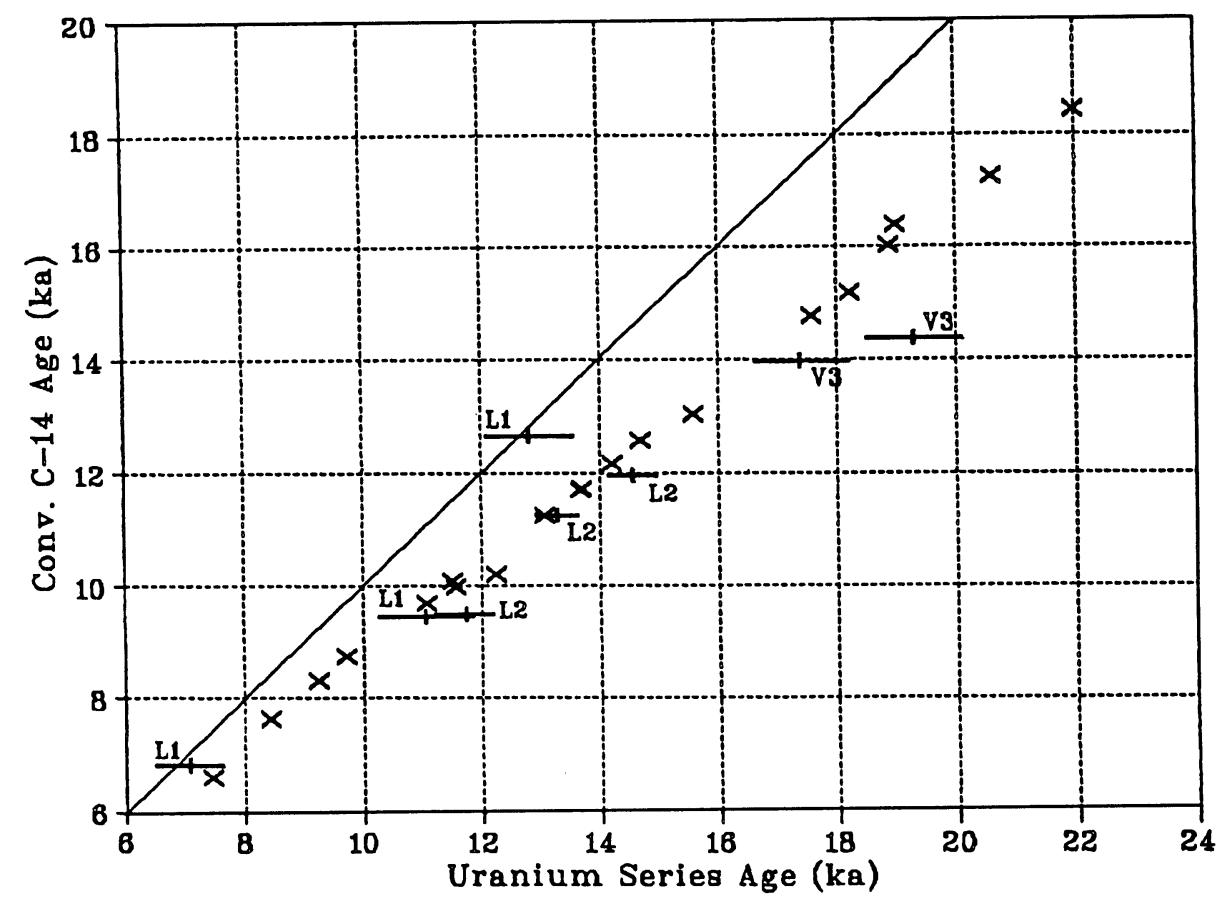

Fig. 2. Calibration curve for conventional ${ }^{14} \mathrm{C}$ dates after Bard et al. (1993) ( $\times$ ) with our age-pairs for the Lynd's Cave stalagmites (L1 and L2) (Table 2) and the two Cango Cave (V3) age-pairs in this time range (Table 1) 
Using the comparisons obtained from the Cango Cave stalagmite, a calibration curve for the period $25 \mathrm{ka}$ to $50 \mathrm{ka}$ is plotted in Figure 3. The four samples with U/Th error margins greater than \pm 2000 $\mathrm{yr}(\mathrm{V} 3 / 6 \mathrm{c}, \mathrm{V} 3 / 3 \mathrm{~b}, \mathrm{~V} 3 / 4 \mathrm{c}$ and $\mathrm{V} 3 / 4 \mathrm{~d})$ are not included in the figure because they are not very meaningful. The margins of error of this curve are still relatively large, but for the present it can be used in cases where absolute date estimates are required rather than ${ }^{14} \mathrm{C}$ ages. It is evident from this figure that ${ }^{14} \mathrm{C}$ dates between $35 \mathrm{ka}$ and $45 \mathrm{ka}$ are ca. $5000 \mathrm{yr}$ too young. Recently, one additional age comparison has been published (Bischoff et al. 1994) that confirms this discrepancy.

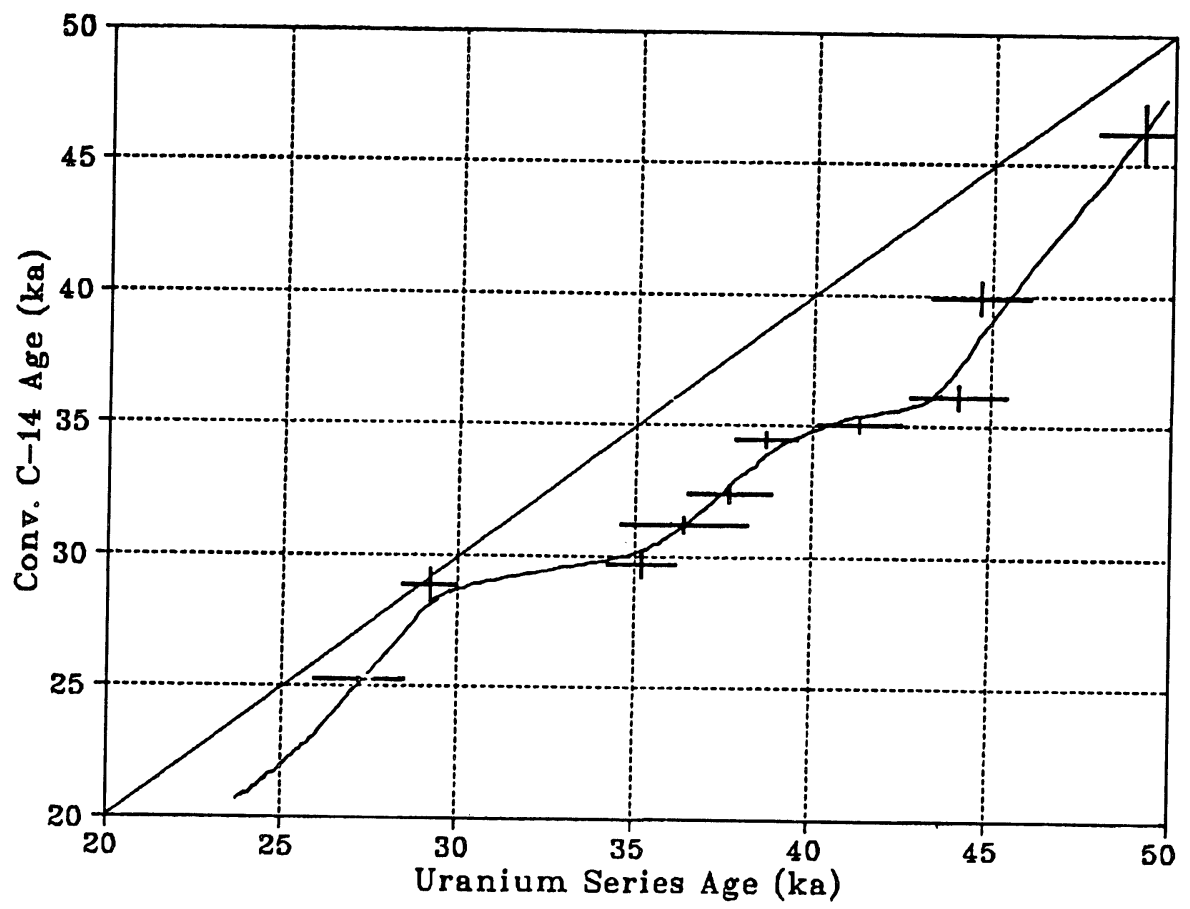

Fig. 3. Calibration curve for conventional ${ }^{14} \mathrm{C}$ dates between $20 \mathrm{ka}$ and $50 \mathrm{ka}$ using the data for the Cango Cave stalagmite, V3 (Table 1)

The authors find that their ${ }^{14} \mathrm{C}$ ages on charcoal $(37 \pm 1 \mathrm{ka})$ are much younger than $\mathrm{U} / \mathrm{Th}$ ages on bracketing flowstone $(42.6 \pm 1.1 \mathrm{ka})$ in a cave near Barcelona, Spain. If the ${ }^{14} \mathrm{C}$ date is calibrated, using Figure 3, it overlaps with the U/Th date.

Not shown in Figure 2 is the isolated coral sample of Bard et al. (1993) that gave an age-pair at variance with our results at ca. $30 \mathrm{ka}$ (Figure 3). Their measurements show the ${ }^{14} \mathrm{C}$ date to be $4780 \pm 380$ (20) yr younger than the U/Th date of $30,225 \pm 160 \mathrm{yr}$, whereas our age-pair at $29,000 \mathrm{yr}$ shows almost no difference between the two techniques: at $29,200 \pm 800 \mathrm{yr}(\mathrm{U} / \mathrm{Th})$ the ${ }^{14} \mathrm{C}$ age is only 350 yr younger. Other age-pairs in this time range, on the other hand, do seem to support our finding: the five comparisons listed by Barbetti (1980) between $26,000 \mathrm{yr}$ and 32,000 yr individually and collectively show virtually no discrepancy between $\mathrm{U} / \mathrm{Th}$ and ${ }^{14} \mathrm{C}$ ages. The weighted averages for these six samples give:

$$
29,690 \pm 680 \mathrm{yr}(\mathrm{U} / \mathrm{Th})-29,800 \pm 760 \mathrm{yr}\left({ }^{14} \mathrm{C}\right)=-110 \pm 1020 \mathrm{yr} .
$$




\section{CONCLUSION}

If ${ }^{14} \mathrm{C}$ dating gives the correct age at $29,000 \mathrm{yr}$, it implies that a drastic decrease in the ${ }^{14} \mathrm{C}$ levels of the atmosphere occurred. This seems to be indicated by the very slow decrease in the ${ }^{14} \mathrm{C}$ ages between the U/Th dates of 35,000 and 29,000 yr (Fig. 1). The effect could have been caused by a major increase in the strength of the Earth's dipole field, and there is some evidence that this did happen. Most estimates of the global dipole field intensity during the last 120,000 yr indicate considerably lower values than today, but at least one of them (Tric et al. 1992) shows near-normal dipole intensity between 55 and $47 \mathrm{ka}$, between 33 and $25 \mathrm{ka}$ and after $12 \mathrm{ka}$, with distinctly lower values in between. The geomagnetic modulation of the ${ }^{14} \mathrm{C}$ production rate could thus explain qualitatively, at least, the general trend of the data presented here.

\section{ACKNOWLEDGMENTS}

We especially thank Professor Hilary Deacon for originally arranging permission to remove the Cango stalagmite for our investigations. Albert Goede supplied the Tasmanian samples. We thank Ebbie Visser for her careful monitoring of the radiocarbon measurements.

\section{REFERENCES}

Barbetti, M. 1980 Geomagnetic strength over the last 50,000 years and changes in atmospheric ${ }^{14} \mathrm{C}$ concentration: Emerging trends. In Stuiver, M. and Kra, R., eds., Proceedings of the 10 th International ${ }^{14} \mathrm{C}$ Conference. Radiocarbon 22(2): 192-199.

Bard E., Arnold, M., Fairbanks, R. G. and Hamelin, B. $1993{ }^{230} \mathrm{Th}-{ }^{234} \mathrm{U}$ and ${ }^{14} \mathrm{C}$ ages obtained by mass spectrometry on corals. In Stuiver, M., Long, A. and Kra, R. S., eds., Calibration 1993. Radiocarbon 35(1): 191-199.

Bard, E., Hamelin, B., Fairbanks, R. G. and Zinder, A. 1990 Calibration of the ${ }^{14} \mathrm{C}$ timescale over the past 30,000 years using mass spectrometric U-Th ages from Barbados corals. Nature 345: 405-410.

Bischoff, J. L., Ludwig, K., Garcia, J. F., Carbonell, E., Stafford, T. W., Jr. and Jull, A. J. T. 1994 Dating of the basal Aurignacian sandwich at Abric Romani (Catalunya, Spain) by radiocarbon and uranium-series. Journal of Archaeological Science 21: 541-551.

Goede, A. and Vogel, J. C. 1991 Trace element variations and dating of a Late Pleistocene Tasmanian Speleothem. Palaeogeography, Palaeoclimatology, Palaeoecology 88: 121-131.

Kromer, B. and Becker, B. 1993 German oak and pine ${ }^{14} \mathrm{C}$ calibration, 7200-9439 BC. In Stuiver, M., Long,

A. and Kra, R. S., eds., Calibration 1993. Radiocarbon 35(1): 125-135.

Stuiver, M. and Pearson, G. W. 1993 High-precision bidecadal calibration of the radiocarbon time scale, $A D$ 1950-500 BC and 2500-6000 BC. In Stuiver, M., Long, A. and Kra, R. S., eds., Calibration 1993. Radiocarbon 35(1): 1-23.

Tric, E., Valet, J. P., Tucholka, P., Paterne, M., Labeyrie, L., Guichard, F., Tauxe, L. and Fontugne, M. $1992 \mathrm{~Pa}$ leointensity of the geomagnetic field during the last eighty thousand years. Journal of Geophysical Research 97: 9337-9351.

Vogel, J. C. 1980 Accuracy of the radiocarbon time scale beyond 15,000 BP. In Stuiver, M. and Kra, R., eds., Proceedings of the 10th International ${ }^{14} \mathrm{C}$ Conference. Radiocarbon 22(2): 210-218.

$1983{ }^{14} \mathrm{C}$ variations during the Upper Pleistocene. In Stuiver, M. and Kra, R., eds., Proceedings of the 11th International ${ }^{14} \mathrm{C}$ Conference. Radiocarbon 25(2): 213-218.

1987 Calibration of radiocarbon dates beyond 10000 BP. In Aurenche, O., Evin, J., and Hours, F., eds., Chronologies in the Near East. BAR International Series 379(i). Oxford, BAR: 319-322. 